Cost Versus Benefit in Cancer Care 


\title{
Cost Versus Benefit in Cancer Care
}

Edited by

\author{
Basil A. Stoll
}

Honorary Consulting Physician to Oncology Departments St Thomas's Hospital and Royal Free Hospital, London

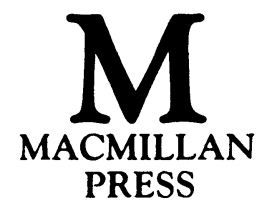


(C) The Editor and the Contributors 1988

Softcover reprint of the hardcover 1st edition 1988

All rights reserved. No reproduction, copy or transmission of this publication may be made without written permission.

No paragraph of this publication may be reproduced, copied or transmitted save with written permission or in accordance with the provisions of the Copyright Act 1956 (as amended), or under the terms of any licence permitting limited copying issued by the Copyright Licensing Agency, 33-4 Alfred Place, London WG1E 7DP.

Any person who does any unauthorised act in relation to this publication may be liable to criminal prosecution and civil claims for damages.

First published 1988

Published by

THE MACMILLAN PRESS LTD

Houndmills, Basingstoke, Hampshire RG21 2XS

and London

Companies and representatives

throughout the world

Photoset by TecSet Ltd. Wallington, Surrey

British Library Cataloguing in Publication Data

Cost vs. benefit in cancer care.

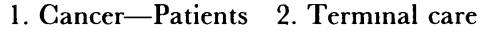

I. Stoll, Basil A.

362.1'96994

RC262

ISBN 978-1-349-09298-7

ISBN 978-1-349-09296-3 (eBook)

DOI 10.1007/978-1-349-09296-3 


\section{Contents}

The Contributors vii

Preface $\quad$ ix

Introduction by Gavin Mooney 1

Part 1 Current Dilemmas 5

1. What is overtreatment in cancer?

Basil A. Stoll
What is best for the patient?' A United States view 19

Aman U. Buzdar

3. What is best for the patient? A European view 31

Gareth J. G. Rees

4. The patient's expectations in the United States 39

Allan S. Brett

5. The physician's attitude in Britain 49

David Radstone

6. Focus on clinical trials $\quad 57$

Elizabeth A. Eisenhauer and William J. Mackillop

\section{Part 2 Future Prospects}

7. Dying with dignily: A United States view $\quad 67$

Bernard Lo and Fenella Rouse

8. Dying with dignily: A British view $\quad 73$

Sam Ahmedzai and Eric Wilkes
9. Rationing cancer care: $A$ United States view Eli Ginzberg 
10. Rationing cancer care: A European view

Gavin Mooney and John Henderson

11. Saying no is difficult in cancer

Basil A. Stoll

Index 


\section{The Contributors}

\section{Sam Ahmedzai, BSc, MRCP}

Medical Director and Honorary Consultant Physician, Leicestershire Hospice, Leicester, UK

\section{Allan S. Brett, MD}

Department of Medicine, New England Deaconess Hospital, Boston, USA

\section{Aman U. Buzdar, MD}

Professor of Medicine, Dept of Medical Oncology (Medical Breast Service), M. D. Anderson Hospital and Tumor Institute, Houston, USA

\section{Elizabeth A. Eisenhauer, MD,} FRCP(C)

Assistant Professor, Depts of Oncology and Medicine, Queen's University, Kingston, Ont., Canada

\section{Eli Ginzberg, PhD}

Director, Conservation of Human Resources, Columbia University, New York, USA

\section{John Henderson, BA, MSc}

Research Fellow, Health Economics

Research Unit, University of Aberdeen, UK

\section{Bernard Lo, MD}

Assistant Professor of Medicine, University of California, USA

William J. Mackillop, MB, ChB, $\operatorname{FRCP}(\mathbf{C})$

Associate Professor, Depts of Oncology and Pathology, Queen's University, Kingston, Ont., Canada

\section{Gavin Mooney, MA}

Professor of Health Economics, Institute of Social Studies, University of Copenhagen, Denmark

\section{David Radstone, FRCR}

Consultant in Radiotherapy and Oncology, Weston Park Hospital, Sheffield, UK

\section{Gareth J. G. Rees, MRCP, FRCR}

Consultant Oncologist, Bristol Radiotherapy and Oncology Centre, Bristol, UK

\section{Fenella Rouse, JD}

Director, Legal Services, Society for the Right to Die, New York, USA 
viii

The Contributors

Basil A. Stoll, FRCR, FFR

Eric Wilkes, FRCP, FRCGP, Honorary

Consulting

Physician,

FRCPsych

Oncology Dept, St Thomas's Hospital, Emeritus Professor, University of London, UK Sheffield, UK 


\section{Preface}

Public discussion has always been cautious on the conditions under which physicians should limit active treatment in advanced disease of all types. Some are afraid that such discussion might undermine public confidence in the profession. However, it is time that physicians shared the responsibility for solving the new ethical dilemmas that have resulted from the spiralling growth of high technology in the last 25 years. These problems are well exemplified in the management of cancer patients.

Although curative measures are only rarely available for the vast majority of patients with advanced solid cancers, there are numerous new agents for investigation, treatment and life support. Such advances in technology are trumpeted in the media and lead to high expectations from the public. Again, peer pressure and sometimes fear of litigation (particularly in the USA) may lead the physician to overinvestigate or overtreat the late cancer patient. The first aim of this book therefore is to examine the benefit from such management relative to the price paid by the patient in terms of diminished quality of life.

The second aim is to examine the benefits of innovative cancer treatments in terms of their cost to society. In the past, physicians have always rationed their time because of the pressures of work. It has now become mandatory to ration the rapidly increasing, expensive high technology which is available. It is obvious that the cost of a cancer treatment should not dictate whether to treat, and in some cases it is right to treat whatever the cost. But the resources of even the most prosperous Western society are limited.

The increasingly aged population, increasing public expectations and proliferation of highly expensive technology with built-in obsolescence, makes it increasingly expensive to provide everything possible to delay death in the late cancer patient - even if this were desirable in all cases. Government funding of the health services faces a crisis both in Europe and the USA. 
In order to focus the inquiry, this book examines the economic and social causes of differences in cancer management between the USA and the UK, and their effect on the quality of life (and quality of death) of the cancer patient. I do not expect that all my colleagues will agree with my conclusion that guidelines are urgently needed for physicians in the treatment of advanced cancer, and that a consensus is required between the two sides of the Atlantic. The book is directed not only at health professionals involved in the clinical care of cancer patients, but also at health economists, sociologists, and all those concerned with medical ethics and the rights of the individual. In fact, the public at large.

London, 1988

B. A. S. 